\title{
MEMBACA NAFAS PENGAKUAN \\ DAN PERLINDUNGAN HAK \\ MASYARAKAT HUKUM ADAT DI \\ INDONESIA $^{1}$
}

Oleh: M. Jamil, S.H. ${ }^{2}$

\section{Pendahuluan}

Tiap-tiap hukum merupakan suatu sistem, yaitu peraturanperaturannya merupakan suatu kebulatan berdasarkan atas kesatuan alam pikiran. Begitu pun hukum adat. Sistem hukum adat bersendi atas dasar-dasar alam pikiran bangsa Indonesia, yang tidak sama dengan alam pikiran yang menguasai sistem hukum barat. Untuk dapat sadar akan sistem hukum adat, orang harus menyelami dasar-dasar alam pikiran yang hidup di dalam masyarakat Indonesia. ${ }^{3}$ Begitu gagasan R. Soepomo yang memandang hukum sebagai suatu sistem.

Istilah hukum adat merupakan terjemahan dari istilah belanda: "Adat-Recht" yang pertama kali dikemukakan oleh Snouck Hurgronje yang kemudian dipakai dalam bukunya "De

${ }^{1}$ Tulisan ini pernah disampaikan sebagai pemantik pada Forum Diskusi Kelas C (FDC) Magister Kenotariatan Fakultas Hukum Universitas Gadjah Mada (MKN FH UGM) Yogyakarta, pada 06 November 2015 di Fakultas Hukum Universitas Gadjah Mada (FH UGM) Yogyakarta. Namun sudah ada pengembangan dalam penulisannya.

${ }^{2}$ Ketua Umum Pusat Studi Mahasiswa Pascasarjana (PUSMAJA) MbojoYogyakarta Periode 2015-2016 | Mahasiswa Magister Kenotariatan Fakultas Hukum Universitas Gadjah Mada (UGM) Yogyakarta, jamilncera@gmail.com | All About Me kunjungi www.mjamil.my.id.

${ }^{3}$ R. Soepomo, 1996, Bab-Bab Tentang Hukum Adat, cet. ke-14, Jakarta: PT. Pradnya Paramita, hlm. 21. 
Atjehers" (orang-orang Aceh). ${ }^{4}$

Undang-Undang Nomor 5 Tahun 1960, yang dikenal sebagai Undang-Undang Pokok Agraria (UUPA), mengenal hak ulayat. Pengakuan ini merupakan wujud nyata pengakuan terhadap masyarakat adat. Pengakuan semakin kuat setelah Mahkamah Konstitusi memutuskan status hutan adat dalam putusan No. 35/PUU-X/2012. RUU Pengakuan dan Perlindungan Hak Masyarakat Hukum Adat - RUU Perlindangan Masyarakat Adat - adalah upaya menuju pengakuan yang lebih kuat. ${ }^{5}$

Masyarakat Hukum Adat adalah Warga Negara Indonesia yang memiiki karakteristik khas, hidup berkelompok secara harmonis sesuai hukum adatnya, memiliki ikatan pada asal usul leluhur dan atau kesamaan tempat tinggal, terdapat hubungan yang kuat dengan tanah dan lingkungan hidup, serta adanya sistem nilai yang menentukan pranata ekonomi, politik, sosial, budaya, hukum dan memanfaatkan satu wilayah tertentu secara turun temurun. ${ }^{6}$

Hukum adat memiliki karakteristik tersendiri sebagai sumber hukum yang sebagian besar bersifat tidak tertulis. Hilman Hadikusuma mengemukakan bahwa "Hukum Adat kebanyakan tidak ditulis, walaupun ada juga yang dicatat dalam aksara daerah, bahkan ada yang dibukukan dengan cara yang tidak sistematis, namun hanya sekedar sebagai pedoman bukan mutlak harus dilaksanakan, kecuali yang bersifat perintah Tuhan. Jadi, Hukum Adat pada umumnya tidak dikodifikasi seperti Hukum Barat (Eropa), yang disusun secara teratur dalam kitab yang

4 Imam Sudiyat, 1991, Asas-Asas Hukum Adat Bekal Pengantar, Yogyakarta: Liberty, hlm. 1.

Hukum Online, 2013, "AMAN Konsultasikan RUU Perlindungan Masyarakat Adat", www.hukumonline.com, diakses 4 November 2015.

${ }^{6}$ Bunyi Pasal 1 Ayat 1 Peraturan Menteri Dalam Negeri Nomor 52 Tahun 2014 Tentang Pedoman Pengakuan dan Perlindungan Masyarakat Hukum Adat. 
disebut kitab perundangan". 7

Hukum Adat ditinjau berdasarkan pada sumber hukum maupun menurut sistem hukum. Dari sumber hukum, maka Hukum Adat adalah bagian dari sumber hukum formil. Hukum Adat ditinjau dari sistem hukum di Indonesia adalah bagian dari sistem hukum dalam sistem hukum nasional, yang bertumpu pada Sistem Hukum Barat (Eropa), Sistem Hukum Adat, dan Sistem Hukum Islam. Sistem Hukum (legal system) itu sendiri dirumuskan oleh C.F.G. Sunaryati Hartono, dikatakan bahwa "Karena sistem itu selalu terdiri dari sejumlah unsur atau komponen yang saling berkaitan dan pengaruh-mempengaruhi, lagi pula terikat oleh satu atau beberapa asas tertentu, maka sistem hukum pun terdiri dari sejumlah unsur atau komponen, yang sebagian pada saat ini sudah ada dan sudah berfungsi, tetapi sebagian besar lagi masih harus diciptakan". ${ }^{8}$

Hukum adat tidak mengenal sistem peraturan yang statis. Dengan sendirinya tidak ada sistem hukum pelanggaran adat yang statis pula. Tiap-tiap peraturan hukum adat yang timbul, berkembang dan selanjutnya lenyap dengan lahirnya peraturan baru, sedang peraturan baru itu berkembang juga, tetapi kemudian akan lenyap pula dengan adanya perubahan rasa keadilan yang menimbulkan perubahan peraturan. Begitu seterusnya, keadaannya seperti menggulungnya riak-gelombang di pesisir samudera. ${ }^{9}$

\section{Masyarakat Adat dan Masyarakat Hukum Adat}

\footnotetext{
${ }^{7}$ Rifky Dipalanga, 2013, "Pelaksanaan Upacara Adat Perkawinan Daerah Bolaang Mongondow (Perspektif Hukum Islam)", Jurnal Lex Privatum, Vol.I/No.3/Juli/2013, hlm. 82.

${ }^{8}$ Ibid, hlm. 82.

${ }^{9}$ Imam Sudiyat, 2007, Hukum Adat Sketsa Asas, cet. Ke-5, Yogyakarta: Liberty, hlm. 176-177.
} 
1. Pengeritan Masyarakat Adat

Draf Rancangan Undang-Undang tentang Pengakuan dan Perlindungan Hak Masyarakat Hukum Adat (RUU PPHMHA) yang di buat oleh Aliansi Masyarakat Adat Nusantara (AMAN) memberi pengertian bahwa, "masyarakat adat adalah kelompok masyarakat yang secara turun temurun bermukim di wilayah geografis tertentu di Negara Indonesia karena adanya ikatan pada asal usul leluhur, adanya hubungan yang kuat dengan tanah, wilayah dan sumber daya alam di wilayah adatnya, serta adanya sistem nilai yang menentukan Rancangan Undang-Undang tentang Pengakuan dan Perlindungan Masyarakat Adat pranata ekonomi, politik, sosial dan hukum yang berbeda, baik sebagian maupun seluruhnya dari masyarakat pada umumnya". ${ }^{10}$

Pemerintah memberi pengertian, "Masyarakat Hukum Adat adalah sekelompok orang yang secara turun temurun bermukim di wilayah geografis tertentu di Negara Indonesia karena adanya ikatan pada asal usul leluhur, hubungan yang kuat dengan tanah, wilayah, sumber daya alam, memiliki pranata pemerintahan adat, dan tatanan hukum adat di wilayah adatnya". ${ }^{11}$

2. Pengakuan Hak Masyarakat Hukum Adat

Draf RUU PPHMHA versi Aliansi Masyarakat Adat Nusantara (AMAN) memberi pengertian, "Pengakuan hak masyarakat adat adalah pernyataan tertulis maupun tidak tertulis atas keberadaan masyarakat adat beserta hak-haknya yang diberikan oleh negara dan/atau pihak-pihak lain diluar

${ }^{10}$ Pasal 1 Ayat 1 Rancangan Undang-Undang Republik Indonesia Tentang Pengakuan dan Perlindungan Hak Masyarakat Hukum Adat. (RUU PPHMHA versi AMAN).

${ }^{11}$ Pasal 1 Ayat 1 RUU PPHMA versi Pemerintah. 
negara". 12

Draf RUU PPHMHA versi Pemerintah memberi pengertian, "Pengakuan Hak Masyarakat Hukum Adat adalah pernyataan tertulis atas keberadaan Masyarakat Hukum Adat beserta hak-haknya yang diberikan oleh Negara". ${ }^{3}$

3. Perlindungan Masyarakat Adat

Draf RUU PPHMHA versi Aliansi Masyarakat Adat Nusantara (AMAN) memberi pengertian, "Perlindungan masyarakat adat adalah suatu bentuk pelayanan yang wajib diberikan oleh negara kepada masyarakat adat dalam rangka menjamin terpenuhi hak-haknya, agar dapat hidup tumbuh dan berkembang sebagai satu kelompok masyarakat, berpartisipasi sesuai dengan harkat dan martabat kemanusiannya serta terlindungi dari tindakan diskriminasi" ${ }^{14}$

Draf RUU PPHMHA versi Pemerintah memberi pengertian, "Perlindungan Hak Masyarakat Hukum Adat adalah suatu bentuk pelayanan yang wajib diberikan oleh negara kepada Masyarakat Hukum Adat dalam rangka menjamin terpenuhi hak-haknya, agar dapat hidup tumbuh dan berkembang sebagai satu kelompok masyarakat, berpartisipasi sesuai dengan harkat dan martabat kemanusiannya serta terlindungi dari tindakan diskriminasi dan kekerasan". ${ }^{15}$

\section{Istilah Masyarakat Hukum Adat dalam Perundang- Undangan}

\footnotetext{
${ }^{12}$ Pasal 1 Ayat 2 RUU PPHMHA versi AMAN.

${ }^{13}$ Pasal 1 Ayat 2 RUU PPHMHA versi Pemerintah.

${ }^{14}$ Pasal 1 Ayat 3 RUU PPHMHA versi AMAN.

${ }^{15}$ Pasal 1 Ayat 3 RUU PPHMHA versi Pemerintah.
} 
Kalau kita telurusuri dengan seksama, banyak kita istilah masyarakat hukum adat. Bahkan istilah tersebut dapat kita temukan pengakuan resminya seperti yang tercantum dalam berbagai peraturan perundang-undangan, seperti dalam UndangUndang Nomor 5 Tahun 1960 Tentang Pokok Agraria (UUPA), Undang-Undang Nomor 4 Tahun 2009 Tentang Pertambangan, Undang-Undang Kehutanan, Undang-Undang Nomor 32 Tahun 2004 Tentang Pemerintahan Daerah, dan peraturan perundangundangan lainnya sebagai padanan dari rechtgemeenschapt, atau oleh sedikit literatur menyebutnya adatrechtgemenschap. Istilah masyarakat hukum adat dilahirkan dan digunakan oleh pakar hukum adat yang lebih banyak difungsikan untuk keperluan teoritik-akademis. Sedangkan istilah masyarakat adat adalah istilah yang lazim diungkapkan dalam bahasa sehari-hari oleh kalangan non-hukum yang mengacu pada sejumlah kesepakatan internasional. $^{16}$

\section{Pengakuan dan Perlindungan Hak Masyarakat Hukum Adat}

Pengakuan dan perlindungan hak masyarakat hukum adat dalam peraturan perundang-undangan, dapat ditemukan dalam:

1. Undang-Undang Dasar Negara Republik Indonesia Tahun 1945, dapat di temukan dalam Pasal 18B ayat (2), Pasal 20, Pasal 21, Pasal 28I ayat (3), dan Pasal 32 ayat (1).

2. Undang-Undang Nomor 5 Tahun 1960 Tentang Pokok Agraria (UUPA)

3. Undang-Undang Nomor 41 Tahun 1999 Tentang Kehutanan, terdapat dalam Pasal 67 ayat (1)

16 Taqwaddin, 2010, "Penguasaan Atas Pengelolaan Hutan Adat oleh Masyarakat Hukum Adat (Mukim) di Provinsi Aceh", Disertasi Doktor Ilmu Hukum, Universitas Sumatera Utara, hlm. 36. 
4. Peraturan Daerah Khusus Provinsi Papua Nomor 23 Tahun 2008 Tentang Hak Ulayat Masyarakat Hukum Adat dan Hak Perorangan Warga Masyarakat Hukum Adat Atas Tanah

5. Peraturan Daerah Khusus Provinsi Papua Nomor 21 Tahun 2008 Tentang Pengelolahan Hutan Berkelanjutan di Provinsi Papua

6. Peraturan Menteri Dalam Negeri Nomor 52 tahun 2014 tentang Pedoman dan Perlindungan Masyarakat Hukum Adat

Pada masa pasca Orde Baru sejak tahun 1998 ada banyak Undang-Undang yang dibuat oleh pemerintah bersamasama dengan Dewan Perwakilan Rakyat Republik Indonesia (DPR RI) yang mengatur mengenai keberadaan dan hak-hak masyarakat adat. Kurun waktu 15 tahun sejak 1999 sampai tahun 2014 telah terdapat sekurang-kurangnya enam belas UndangUndang yang mengatur keberadaan dan hak-hak masyarakat hukum adat. Undang-undang tersebut antara lain ${ }^{17}$ :

1. Undang-Undang Nomor 39 Tahun 1999 tentang Hak Asasi Manusia

2. Undang-Undang Nomor 41 Tahun 1999 tentang kehutanan

3. Undang-Undang Nomor 22 Tahun 2001 tentang Minyak dan Gas Bumi

4. Undang-Undang Nomor 20 Tahun 2003 tentang Sistem Pendidikan Nasional

5. Undang-Undang Nomor 24 Tahun 2003 tentang Mahkamah Konstitusi

6. Undang-Undang Nomor 27 Tahun 2003 tentang Panas Bumi

7. Undang-Undang Nomor 7 Tahun 2004 tentang Sumber Daya Air

${ }^{17}$ Kurnia Warman, "Peta Perundang-undangan tentang Pengakuan Hak Masyarakat Hukum Adat", http://procurementnotices.undp.org/view file.cfm?doc id=39284, File PDF, Hlm. 5-6. Diakses 5 November 2015. 
8. Undang-Undang Nomor 18 Tahun 2004 tentang Perkebunan

9. Undang-Undang Nomor 31 Tahun 2004 tentang Perikanan

10. Undang-Undang Nomor 26 Tahun 2007 tentang Penataan Ruang

11. Undang-Undang Nomor 27 Tahun 2007 tentang Pengelolaan Wilayah Pesisir dan Pulau-pulau Kecil

12. Undang-Undang Nomor 30 Tahun 2009 tentang Ketenagalistrikan

13. Undang-Undang Nomor 32 Tahun 2009 tentang Perlindungan dan Pengelolaan Lingkungan Hidup

14. Undang-Undang Nomor 18 Tahun 2013 tentang Pencegahan dan Pemberantasan Perusakan Hutan

15. Undang-Undang Nomor 1 Tahun 2014 tentang Perubahan atas Undang-Undang Nomor 27 Tahun 2007 tentang Pengelolaan Wilayah Pesisir dan Pulau-pulau Kecil

16. Undang-Undang Nomor 6 Tahun 2014 tentang Desa

Di samping itu pengaturan keberadaan dan hak-hak masyarakat hukum adat juga terdapat di dalam beberapa undangundang otonomi khusus sebagai berikut:

1. Undang-Undang Nomor 21 Tahun 2001 tentang Otonomi Khusus Bagi Provinsi Papua

2. Undang-Undang Nomor 11 Tahun 2006 tentang Pemerintahan Aceh

3. Undang-Undang Nomor 13 Tahun 2012 tentang Keistimewaan Daerah Istimewah Yogyakarta

Pengakuan dan perlindungan hak masyarakat hukum adat banyak juga di jumpai dalam putusan-putusal, beberapa diantaranya:

1. Putusan Mahkamah Konstitusi Nomor 35/PUU-X/2012

2. Putusan Mahkamah Agung tanggal 5 November 1957, 
Nomor $130 \mathrm{~K} / \mathrm{Sip} / 1957^{18}$

3. Putusan Mahkamah Agung tanggal 20 April 1960, Nomor $110 \mathrm{~K} / \mathrm{Sip} / 1960^{19}$

4. Putusan Mahkamah Agung perihal Yurisprensi terkait hukum adat Indonesia dapat dibaca lebih lengkap dalam bukunya $\mathrm{R}$. Subekti dengan judul "Hukumn Adat Indonesia dalam Yurisprensi Mahkamah Agung".

\section{Kriteria Eksistensi Masyarakat Hukum Adat}

Satcipto Rahardjo mengungkakan empat klausula yuridis yang menjadi kriteria eksistensi masyarakat hukum adat disertai komentarnya sebagai berikut ${ }^{20}$ :

1. Sepanjang masih hidup

Kita tidak semata-mata melakukan pengamatan dari luar, melainkan juga dari dalam, dengan menyalami perasaan masyarakat setempat (pendekatan partisipatif).

2. Sesuai dengan perkembangan masyarakat

Syarat ini mengandung resiko untuk memaksakan (imposing) kepentingan raksasa atas nama "perkembangan masyarakat". Tidak member peluang untuk membiarkan dinamika masyarakat setempat berproses sendiri secara bebas.

3. Sesuai dengan prinsip NKRI

Kelemahan paradigma ini melihat NKRI dan

${ }^{18}$ R. Subekti, 1990, Hukumn Adat Indonesia dalam Yurisprensi Mahkamah Agung, Cet. Ke-4, Bandung: Alumni, Hlm. 1.

${ }^{19}$ Ibid, hlm. 2.

${ }^{20}$ Hendra Nurtjahjo dan Fokky Fuad, 2010, Legal Standing Kesatuan Masyarakat Hukum Adat dalam Berperkara di Mahkamah Konstitusi, Jakarta: Salemba Humanika, hlm. 97. 
masyarakat adat sebagai dua antitas yang berbeda dan berhadap-hadapan.

4. Diatur dalam undang-undang"

Indonesia adalah Negara berdasar hukum, apabila dalam Negara yang demikian itu segalanya diserahkan kepada hukum, maka kehidupan sehari-hari tidak akan berjalan dengan produktif. Hukum yang selalu ingin mengatur ranahnya sendiri dan merasa cakap untuk itu telah gagal (bila tidak melibatkan fenomena sosial lainnya).

\section{Konflik Adat dan Aspek Hukum dalam Penyelesainnya}

Biasanya konflik adat terjadi antara warga desa dengan sesamanya, antara warga desa atau sekelompok dengan desa. Latar belakang terjadinya konflik adat antara lain disebabkan oleh adanya perubahan sosial yang tanpak pada perubahan perilaku warga masyarakat, dan terjadinya pergeseran nilai budaya. ${ }^{21}$

Ketika dalam penyelesaian konflik adat, harus terlebih dahulu dipahami aturan hukum adat mana yang dilanggar dan yang dapat dijadikan dasar untuk menyelesaikannya. Dalam penyelesaian konflik adat tidak ada yang menang atau kalah, melainkan diupayakan agar keseimbangan yang terganggu pulih kembali, dan para pihak yang bersengketa dapat berhubungan secara harmonis. $^{22}$

Ada 3 upaya untuk menyelesaikan konflik adat dengan pendekatan hukum adat yakni berdasarkan asas rukun, patut dan laras, seperti yang dikemukakan oleh Koesnoe sebagaimana

${ }^{21}$ I Nyoman Sirtha, 2008, Aspek Hukum dalam Konflik Adat di Bali, Bali: Udayana University Press, hlm. 75.

${ }^{22} \mathrm{Ibid}, \mathrm{hlm} .78$. 
dikutip oleh I Nyoman Sirtha, dan diuraikan sebagai berikut ${ }^{23}$ :

1. Asas Rukun

Penerapan asas rukun dalam penyelesaian konflik adat dimaksudkan untuk mengembalikan keadaan kehidupan seperti keadaan semula, status dan kehormatannya, serta mewujudkan hubungan yang harmono sesama krama desa. Asas rukun tidak menekankan menang kalah pada salahsatu pihak, melainkan mewujudkan kembali keseimbangan yang terganggu, sehingga para pihak yang bertikai bersatu kembali dalam ikatan desa adat. Namun apabila konflik adat demikian berat, dan tidak dapat diselesaikan dengan pendekatan asas rukun, maka dapat diterapkan ajaran memutuskan, yakni adanya langkah yang bersifat tegas dan jelas mengenai hak dan kewajiban krama desa masingmasing. Keputusan yang diambil lebih banyak dibimbing oleh perhitungan yang rasional

2. Asas Patut

Pendekatan asas patut dimaksudkan agar penyelesaian konflik adat dapat menjaga nama baik pihak masing-masing, sehingga tidak ada yang merasa diturunkan atau direndahkan status dan kehormatannya selaku krama $\operatorname{desa}^{24}$.

${ }^{23} \mathrm{Ibid}$, hlm. 78-81.

${ }^{24}$ Menurut S.S.T Wisnu Sasangka, seorang pakar bahasa Jawa, mengatakan bahwasannya penamaan Krama Desa sebenarnya merupakan olok-olok yang dilakukan orang kota terhadap orang desa. Saat itu orang yang tak dapat berbahasa dengan benar menurut orang Nagari (orang kota) diidentikkan dengan orang desa sehingga bahasa krama yang digunakan disebut Krama Desa. Lihat Fay Ahmed, 2010, "Salah Kaprah dalam Krama Desa", http://www.kompasiana.com, diakses 6 November 2015. Yang penulis paparkan ini adalah makna Krama Desa dalam bahasa Jawa, namun dalam contoh kasus yang penulis paparkan sebagai contoh adalah terkait konflik adat di Bali, untuk makna Krama Desa dalam bahasa Bali perlu penulis telusuri 


\section{Asas Laras}

Asas laras dalam hukum adat digunakan dalam menyelesaikan konflik adat yang kongkret dengan bijaksana, sehingga para pihak yang bersangkutan dan masyarakat adat merasa puas.

\section{Urgensi Pengesahan RUU PPHMHA}

70 tahun sudah kini kemerdekaan Negara Kesatuan Republik Indonesia. Namun sampai hari ini, Undang-Undang yang diamanatkan konstitusi pada Pasal 18B ayat (2) UUD 1945 belum juga disyahkan. Berbagai masalah dihadapi oleh masyarakat adat sebagai akibat dari 70 tahun pengabaian atas hak-hak konstitusional masyarakat adat termasuk: pemiskinan, pembunuhan, konflik, kriminalisasi, kemusnahan bahasa. Krisis identitas terus meluas dan kualitas lingkungan hidup terus menurun, berdampak pada semakin memburuknya kesehatan dan kesejahteraan masyarakat adat di seluruh pelosok Nusantara. ${ }^{25}$

Kebutuhan akan adanya sebuah undang-undang yang mengatur mengenai masyarakat adat telah lama didorong oleh organisasi masyarakat adat seperti Aliansi Masyarakat Adat Nusantara (AMAN), dan bahkan telah disambut oleh DPR RI dengan menyiapkan Draf Rancangan Undang-Undang (RUU) tentang Pengakuan dan Perlindungan Hak Masyarakat Hukum Adat (RUU PPHMHA). Kebutuhan akan sebuah Undang-Undang tentang Masyarakat Hukum Adat juga disampaikan oleh Mahkamah Konsitusi dalam Putusan MK No. 35/PUU-X/2012. ${ }^{26}$ Hakim konstitusi menyampaikan bahwasannya Undang-Undang yang diperintahkan Pasal 18B ayat (2) UUD $1945^{27}$ hingga saat

\section{lebih lanjut.}

25 Aman, 2015, "Deklarasi Tanah Air", www.aman.or.id, diakses 4 November 2015.

${ }^{26}$ Putusan MK No. 35/PUU-X/2012, hlm 184.

${ }^{27}$ Pasal 18B ayat (2) UUD 1945 hasil amandemen kedua berbunyi "Negara 
ini belum terbentuk. Hal yang sama juga terungkap dalam Simposium Masyarakat Adat II "Gerakan Masyarakat Adat dan Pembaruan Hukum" menyambut 3 tahun Putusan MK No. 35/PUU-X/2012 yang diadakan Universitas Pancasila, Jakarta, Senin 16 Mei 2016, dalam simposium tersebut terungkap bahwa tiga tahun sejak keputusan Mahkamah Konstitusi Nomor 35 ditetapkan, hingga kini belum ada satu pun hak masyarakat hukum adat di Indonesia yang diakui pemerintah. Padahal, masyarakat hukum adat bagian dari sejarah berdirinya Negara. ${ }^{28}$ Oleh karena kebutuhan yang mendesak, banyak peraturan perundang-undangan yang lahir sebelum Undang-Undang yang dimaksud terbentuk. ${ }^{29}$

Selain yang dipaparkan penulis diatas, ada beberapa point penting kenapa perlunya peraturan khusus yang melindungi masyarakat adat, seperti yang di tulis Sopian Hadi, diantaranya ${ }^{30}$ :

1. Untuk menjamin perlindungan hak masyarakat adat terhadap hak atas tanah, wilayah, budaya, dan sumber daya alam yang diperoleh secara turun-temurun atau pewarisan dari leluhur mereka. Di tingkat lokal, adanya peraturan dimaksud menjadi payung hukum bagi pemerintah daerah untuk membentuk peraturan daerah yang memihak kepada masyarakat adat.

\footnotetext{
mengakui dan menghormati kesatuan-kesatuan masyarakat hukum adat beserta hak-hak tradisionalnya sepanjang masih hidup dan sesuai dengan perkembangan masyarakat dan prinsip Negara Kesatuan Republik Indonesia, yang diatur dalam undang-undang."

${ }^{28}$ Lihat Koran Kompas, "Masyarakat Adat: Pemerintah Belum Akui Satu Pun Hak Adat", Terbit 17 Mei 2016.

${ }^{29}$ Kurnia Warman, "Peta Perundang-undangan tentang Pengakuan Hak Masyarakat Hukum Adat", http://procurementnotices.undp.org/view file.cfm?doc $\mathrm{id}=39284$, File PDF, Hlm. 3. Diakses 5 November 2015.

${ }^{30}$ Sopian Hadi, 2014, "Pengakuan Masyarakat Adat", www.kompasiana.com, diakses 28 Oktober 2015.
} 
2. Memberikan jaminan perlidungan bagi masyarakat adat dari tindakan diskriminasi dan kekerasan. Karena tidak jarang kita mendengar, banyak masyarakat adat yang diintimidasi oleh perusahaan. Dengan adanya peraturan yang memberikan pengakuan kepada masyarakat adat, diharapkan tidak ada lagi sengketa lahan antara masyarakat adat yang telah lama memanfaatkan hutan, berhadapan dengan perusahaan sawit, tambang, karet dan sebagainya.

3. Memberikan kepastian hukum bagi masyarakat adat dalam melaksanakan haknya. Masyarakat adat selama ini menjadikan hutan sebagai "Ibu". Hutan memberikan mereka segalanya, tempat bertani, berburu, dan mencari makan. Ketika pemerintah mengeluarkan izin usaha pemanfaatan hutan kepada pihak swasta di kawasan hutan adat, dampak bagi masyarakat adat tidak bisa dihindarkan. Hutan yang sebelumnya dikelola masyarakat adat secara turun menurun untuk memenuhi penghidupan sehari-hari, tergusur dengan adanya ekspansi perusahaan.

\section{Kesimpulan dan Saran}

Dari uraian yang penulis paparkan diatas, sebenarnya pengakuan masyarakat hukum adat sudah banyak diatur dalam peraturan perundang-undangan yang berlaku. Banyaknya peraturan tersebut, bukan berarti tanpa hambatan, banyak juga persoalan-persoalan yang dihadapi oleh masyarakat hukum adat. Krisis identitas terus meluas dan kualitas lingkungan hidup terus menurun, berdampak pada semakin memburuknya kesehatan dan kesejahteraan masyarakat adat di seluruh pelosok Nusantara.

Mengingat pengakuan masyarakat hukum adat di Indonesia, Mahkamah Konstitusi pun ketika ada ketimpangan hukum mengeluarkan Putusan MK No. 35/PUU-X/2012, yakni 
mengembalikan roh pengakuan masyarakat hukum adat seperti diperintahkan Pasal 18B ayat (2) UUD 1945. Tiga tahun sejak keputusan Mahkamah Konstitusi Nomor 35 ditetapkan, hingga kini belum ada satu pun hak masyarakat hukum adat di Indonesia yang diakui pemerintah. Padahal, masyarakat hukum adatmerupakan bagian dari sejarah berdirinya Negara Kesatuan Republik Indonesia (NKRI).

Oleh karenanya, penulis menyarankan perlu kiranya untuk disegerakan pengesahan Rancangan Undang-Undang Republik Indonesia Tentang Pengakuan dan Perlindungan Hak Masyarakat Hukum Adat (RUU PPHMHA) agar menjadi Undang-Undang yang menjadi bahan bijakan bagi seluruh masyarakat hukum adat serta pemangku kepentingan, setelah menjadi Undang-Undang masyarakat hukum adat secara de facto dan de jure lebih kuat perlindungan hak-haknya yang telah diamanahkan oleh UndangUndang Dasar Negara Republik Indonesia Tahun 1945. 


\section{DAFTAR PUSTAKA}

Ahmed, Fay, 2010, "Salah Kaprah dalam Krama Desa", http://www.kompasiana.com, diakses 6 November 2015.

Aman, 2015, "Deklarasi Tanah Air", www.aman.or.id, diakses 4 November 2015.

Dipalanga, Rifky, 2013, "Pelaksanaan Upacara Adat Perkawinan Daerah Bolaang Mongondow (Perspektif Hukum Islam)", Jurnal Lex Privatum, Vol.I/No.3/Juli/2013.

Hendra Nurtjahjo dan Fokky Fuad, 2010, Legal Standing Kesatuan Masyarakat Hukum Adat dalam Berperkara di Mahkamah Konstitusi, Jakarta: Salemba Humanika.

Hadi, Sopian, 2014, "Pengakuan Masyarakat Adat", www.kompasiana.com, diakses 28 Oktober 2015.

Koran Kompas, "Masyarakat Adat: Pemerintah Belum Akui Satu Pun Hak Adat", Terbit 17 Mei 2016.

Online, Hukum, 2013, "AMAN Konsultasikan RUU Perlindungan Masyarakat Adat", www.hukumonline.com, diakses 4 November 2015.

Putusan MK No. 35/PUU-X/2012.

Peraturan Menteri Dalam Negeri Nomor 52 Tahun 2014 Tentang Pedoman Pengakuan dan Perlindungan Masyarakat Hukum Adat.

Rancangan Undang-Undang Republik Indonesia Tentang Pengakuan dan Perlindungan Hak Masyarakat Hukum Adat. (RUU PPHMHA versi AMAN).

Rancangan Undang-Undang Republik Indonesia Tentang Pengakuan dan Perlindungan Hak Masyarakat Hukum Adat. (RUU PPHMHA versi Pemerintah). 
Sudiyat, Imam, 1991, Asas-Asas Hukum Adat Bekal Pengantar, Yogyakarta: Liberty. , 2007, Hukum Adat Sketsa Asas, cet. Ke-5, Yogyakarta: Liberty.

Sirtha, I Nyoman, 2008, Aspek Hukum dalam Konflik Adat di Bali, Bali: Udayana University Press.

Subekti, R., 1990, Hukumn Adat Indonesia dalam Yurisprensi Mahkamah Agung, Cet. Ke-4, Bandung: Alumni.

Soepomo, R., 1996, Bab-Bab Tentang Hukum Adat, cet. ke-14, Jakarta: PT. Pradnya Paramita.

Taqwaddin, 2010, "Penguasaan Atas Pengelolaan Hutan Adat oleh Masyarakat Hukum Adat (Mukim) di Provinsi Aceh”, Disertasi Doktor Ilmu Hukum, Fakultas Hukum, Universitas Sumatera Utara.

Undang-Undang Dasar Negara Republik Indonesia Tahun 19945.

Warman, Kurnia, "Peta Perundang-undangan tentang Pengakuan Hak Masyarakat Hukum Adat", http://procurementnotices.undp.org/view file.cfm?doc id=39284, Diakses 5 November 2015.

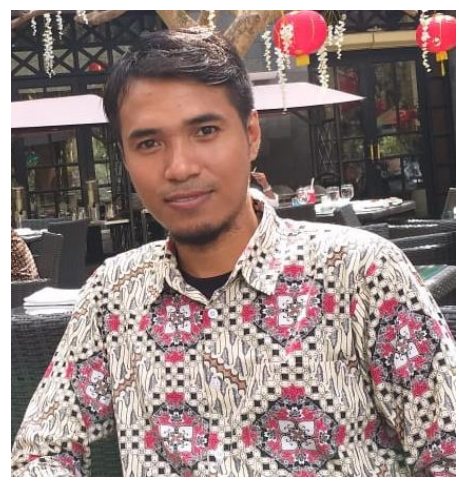

Penulis: M. Jamil, S.H.

Ketua Umum Pusat Studi Mahasiswa Pascasarjana (PUSMAJA) MbojoYogyakarta Periode 2015-2017 Ketua II Bagian Eksternal Dewan Pimpinan Cabang Perhimpunan Mahasiswa Hukum Indonesia Daerah Istimewa Yogyakarta (DPC PERMAHI DIY) Periode 2012-2014 